\title{
Teacher Readiness and Information and Communications Technology (ICT) Use in Classrooms: A South African Case Study
}

\author{
Vuyisile Msila \\ Institute for African Renaissance Studies, College of Graduate Studies, University of South Africa, \\ Pretoria, South Africa \\ Email: msilavt@unisa.ac.za
}

Received 14 August 2015; accepted 26 October 2015; published 29 October 2015

Copyright (c) 2015 by author and Scientific Research Publishing Inc. This work is licensed under the Creative Commons Attribution International License (CC BY). http://creativecommons.org/licenses/by/4.0/

\section{(c) (i) Open Access}

\section{Abstract}

Throughout the world, there have been efforts to transform the $21^{\text {st }}$ century classrooms by introducing digital technology. Districts have been preparing their teachers to use ICT in classrooms thus ensuring that their schools are on the right path for globalisation. Recently, in one South African province Gauteng, the Minister of Education announced that from 2015 tablets would be introduced for teachers and learners as the traditional chalkboard would be replaced by digital technology. This qualitative study sought to explore the views of teachers in that (Gauteng) province. Twenty-five teachers from five schools were observed as they used ICT to teach in their classrooms. Semi-structured interviews were also used in soliciting the teachers' views. The conclusions show that although many teachers are agreeable to change initiatives and innovations in education, ICT can present much uncertainty and the majority are made to feel inadequate. Teachers maintain that without proper training, computers will expose their inadequacies in the classroom. The younger teachers were more tolerant of the changes than their older counterparts who found the introduction of ICT daunting. The study's conclusions illustrate that the success of digital technology in classrooms will depend more on teacher competence as well as positive attitudes towards ICT.

\section{Keywords}

Innovations, Teacher Change, Technology in Classrooms, Professional Development 


\section{Introduction: The Present Century and Teachers}

Generally, there has been much pressure on teachers in the $21^{\text {st }}$ century schools to improve their instruction. Furthermore, there is a variety of teaching resources that teachers can use currently when one compares with the teaching resources of three to four decades ago. The cell phone, television and projectors are among the implements used in today's digital classrooms and these are revolutionising teaching and learning in schools. In South Africa recently (2014), the Gauteng Province's Minister of Education announced his plans of implementing a new teaching strategy where tablets would be used by both teachers and pupils. This means that chalkboard and the written class notes as well as textbooks will soon be instruments of the past. Yet, even this can be received differently as one moves from community to community and individual to individual. This paper followed up an earlier study I conducted in 2009 where teachers raised concerns about computers "taking over" their classrooms. But then the exposure to computers was not as widespread as they were today in South Africa. Numerous studies have demonstrated how computers can assist in second language as well as science teaching (Jalali \& Panahzade, 2014; Singh \& Chan, 2014; Correos, 2014). Singh \& Chan (2014) contend that the use of ICT in classrooms brings forth a powerful learning environment that transforms the learning and teaching process. Effective information and communications technology (ICT) in classrooms though, demands teachers who are enthusiastic about their use. "One of the factors that determine the development and innovation in public education is the teachers because they are the people who use ICT investment for the development of education. This is because technology does not have an educational value in itself" (Singh \& Chan, 2014: p. 875). Correos (2014) also concures when he points out that the level of teachers' ICT competence is crucial in the use of ICT in classrooms.

Many questions have been posed whether ICT will indeed improve learning and teaching in schools. Domalewska (2014) demonstrates positive pedagogical implications of modern technology for the classroom in general. She argued that technology supported and enriched formal instruction. "Technology-supported learning offers integration of learning with student needs and cultural experiences; it plays a substantive role in developing autonomous life-long learners that possess skills and knowledge necessary for achieving success in modern rapidly changing world” (Domalewska, 2014: p. 28).

Curtis (2014) writes about how United Kingdom schools are changing children entering schools into digital natives. Furthermore, Curtis pointed out that recent research demonstrated how six year olds have the same understanding of communication technology as 45 year olds. Soon countries in the developing world may be similarly given the gradual growth of computer use, utilised creatively for various subjects. Soon computers will totally change the meaning of education as the previous generation was used to it. Creative teachers will use technology across disciplines to change education and schooling. Curtis (2014) also adds that technology used in schools must not only better reflect children's life outside the classroom but should also allow them to enhance their digital skills in a way that will continue to be reliable throughout their adult lives. Changing schools and making them digital ensure that children are ready for improved educational standards.

It is usually argued that there is a great technological divide between technologically advanced countries and developing countries. Many developing countries have challenges in closing the technological divide or gap (Giller, 2014). South Africa is a developing country and one can say that naturally, schools will demonstrate the technology gap when it comes to digital technology development. The constantly transforming curriculum and need to develop teachers and teaching may also influence technology education in a number of ways. Giller cites Dutta who argues that the gap shows no signs of closing for very few developing countries are growing fast enough to catch up. Arguably, this might have to do with a number of factors including teacher training, districts' preparedness, as well as the school leaders' preparation in leading change. The Blu Dot Project (Online) reports on how laptops have improved education in African primary schools in Kenya and Rwanda. The aim is to improve primary schools' literacy. In Kenya, the curriculum is loaded in tablets thus practically phasing out the traditional textbook. Furthermore, in countries such as Zambia, computer programmes in tablets are used to replace textbooks and overcome the issue of unskilled teachers (Bluedot, Online).

Carolan et al. (2014) emphasise that there are contexts such as the developing world, where countries are left behind as others progress immensely. The authors argue that there is a need to introduce human-centred technological models that may spark a more inclusive digital educational revolution. One would argue that this human-centred approach needs to be instilled in teachers.

This study explored the following questions: 
- How do teachers see their roles in a digital classroom?

- What would improve their expertise when they use digital technology?

\section{Objectives of the Study}

Motivated by the recent introduction of computers in Gauteng proving the study sought to explore the following objectives:

- How do teachers understand their roles to be in digital classrooms?

- Does the digital classroom imply enhanced pedagogic practices?

- What can help teachers to have positive view of technology?

- What role can schools play in enhancing technology use by teachers?

\section{Does ICT Make a Positive Difference?}

Higgins (2014) argues that there is evidence that ICT can enhance the practice of both pupils and teachers. He also argues though that being merely used in class does not mean that ICT will bring good results. In fact, Higgins cites various studies where there are no links between computer assisted instruction and pupil achievement. This author also (Higgins, 2014) lists three important discoveries in his study:

- The way that computers and technology are used by pupils and teachers are what make the difference;

- Other options to improve pupils' attainment should also be considered; and

- Providing ICT equipment to schools or teachers will not necessarily make a difference.

All the above are very crucial as other people may think computer use equals excellence irrespective of contexts. There are many other aspects that need to be considered in Computer Assisted Instruction (CAI) classrooms. Ndibalema (2014) maintains that there is little evidence on how ICT has been successful in schools mainly because there are no clear ICT educational strategies in place to improve the pedagogical skills for teachers. Ndibalema also argues that aspects such as teachers' willingness, confidence, motivation, feeling, thinking and belief are some of the factors that need to be explored when looking at ICT and classrooms. Chigona et al. (2014) found that ICT can bring various complexities in classrooms. It could be demotivating especially when technology use minimised the role of professional satisfaction. Furthermore, teachers frequently found themselves teaching the technology rather than teaching with it. However, Chigona et al. (2014) also maintain that ICT when taught by motivated teachers properly or effectively, it can close the gap between advantaged and disadvantaged schools.

Sabanci \& Ozyildrims' (2014: p. 241) findings point towards the positive and meaningful relationship between the use of ICT and managing pupil behaviours:

The findings indicated that positive student behaviours occur when ICT and good human relations were used equally. The findings also indicated that when all kinds of teaching materials used with and in ICT are designed to meet students' interests and needs, undesirable behaviours are likely to decrease and teachers can focus on students learning better.

Al Harbi (2014) concurs with the above when he states that ICT in classrooms enables pupils to take on active role in learning rather than their more traditional role of passive observer and listener. Al Harbi adds that teacher knowledge support and management, policy and planning are some of the critical factors that need to be considered if ICT implementation is going to be effective and fruitful.

Al Mulhim (2014) writes about the reasons for low use of ICT in teaching in Saudi Arabian schools. It is interesting to note that these might be shared by various other countries, especially a developing country such as South Africa. Mulhim lists the following as main barriers; lack of access to ICT; lack of training, lack of time (no time for technology). Blackberry \& Woods (2014) contend that it is not realistic to expect teachers to transform their classrooms easily with ICT. Furthermore, these authors suggest the need for teacher mentors if ICT implementation is to be successful. In fact, the mentor is pivotal in planning to change according to Blackberry and Woods.

Various other researchers have demonstrated that even the use of Internet tools can enhance academic achievement. Castano-Munoz et al. (2014) argue that the Internet has a potential to enhance communication and interaction and it can also help the pupils to overcome the barriers of time and space. Furthermore, these authors stress that learning online will be highly effective when it is used as a form of interactive learning. Ermeley et al. 
(2014) also argue that using computerised learning methodology can enhance and speed the teaching process. These authors in their study on teaching gymnast athletics found that computerised learning is effective in enhancing skills, physical abilities as well as achievement. Alnahdi (2014) also writes about how technology is also improving the lives of pupils with disabilities. Alnahdi (2014: p. 21) asserts, "Technology has changed and continues to change the way people manage things in their lives, both in private and in practical life, so the natural extension of that is to see the impact and the integration of technology in education for students with disabilities in the same way it has been in other areas of life". Word processors, spell checking programmes and proof reading programmes are some of the useful technologies that Alnahdi highlights.

\section{Research Methodology}

This qualitative study used a sample of five schools from which twenty five participants were selected. In each school a principal and four teachers who were involved with computers in education were selected. All the participants were interviewed individually using semi-structured interviews. Each interview took a maximum of 50 minutes and all were conducted in the participants' schools. In addition to these interviews, at least two lessons that incorporate computers were observed in each of the five schools. Three of the schools are historically black schools with challenges of physical space as well as human and material resources. The other two are historically Coloured schools situated in the West of Johannesburg. Two of the sampled schools are primary schools and the other three secondary schools. The schools were purposefully selected because they had started computer classes in the past two years. Whilst in two of the sampled schools, computer education was not an examinable subject, all the five schools taught basic computer skills to the pupils.

Sixteen of the participants were experienced teachers who on average had been in the teaching professions for fourteen years. Eleven of the participants were younger teachers who had just qualified from initial teacher training. The average experience among this group was four years. In observing two participants in each of the schools I used unstructured observation which involves the collection of descriptive data that is analysed qualitatively rather than quantitatively (Brink, 2000). In unstructured observations, the observer is not bound by predetermined measuring instruments but searches for concepts and categories as they unravel (Struwig \& Stead, 2004).

Purposive sampling, sometimes referred to as judgmental sampling was employed because it enabled me to select participants who were representative of the topic studied. I was also interested in finding out the participants' readiness in using computers in schools. The advantage of this form of sampling is that it allows the researcher to hand-pick the sample based on knowledge of the area of study (Brink, 2000).

The data analysis process was done through an iterative process which implies that analysis was not conducted through a linear process. Reduction strategies of research were employed to simplify the analysis process. Hamilton \& Corbett-Whittier (2013) describe reduction as that process which involves coding of data. It was after this reduction that I was able to code the various categories from the data.

\section{Results and Discussion}

\subsection{Teachers and Competence}

Teachers argued about their lack of competence in computers. In fact, they were also stating that the call for use of tablets in Gauteng schools comes at a time when they were still trying to understand the revised curriculum in South Africa referred to as Curriculum Assessment Policy Statements (CAPS) which is modified form of the previous National Curriculum Statement. The participants pointed out that it will be challenging to try and fuse computers into their learning of the revised curriculum and they added that any innovation needs teachers who are competent. All the participants concur that ICT and computers can be very effective in enhancing the introduction of any new curricula. However, a number of the participants stated that their competence was affected by three aspects namely teacher isolation, lack of necessary training as well as lack of school leaders who lead in ICT.

The older teachers tended to isolate themselves because they did not want others to see their inadequacy in computers. As one said that it makes one "feel less professional when they do not know what seems to be the basic computer knowledge". The participant declared:

I do not like to expose myself to colleagues. This computer education has made me uncomfortable to share 
what I know and what I do not know. I find it very difficult to be asking for help at all times. It makes one vulnerable. I have been teaching for years without these computers and all of a sudden I am so scared to share what I do not know with others.

\section{Another concurred:}

It is very difficult to ask sometimes because it appears that some of my questions expose my computer ignorance. I am simply waiting for my retirement. I find it difficult to grasp computers now. I will never be competent in these things. Training now is only stressful because there are just so many things to learn in a short space of time. I think schools should rather get new teachers for computers; this is only making us more resentful. These make teaching stressful indeed.

Yet there are others who find the computers in classrooms an opportunity to improve their teaching as well as the skills of their pupils. One pointed out that computers provided a good opportunity to explore various other prospects to improve her teaching. She also perceived it as providing chances for pupils to be well prepared for the future. This participant added:

This computer education is long overdue. I come from university and I struggled in my first year because I knew nothing about computers. Certainly, the learners now will not be like me. By the time they pass grade 12 they will have mastered a certain level of competence. This is a good way to go because the future is computers. It is only a pity that there are several teachers who were never trained in using them. In fact, this lack of competency will stall the progress of computers in education.

It appears all the participants concur that if training can be provided for all teachers, challenges in introducing computers in education will be curbed. All stated that computer competence is highly linked to training and in the absence of proper training competence cannot be expected. However, it was interesting to note that although all saw training and pivotal to competence, others were reluctant to undergo this training "because it would expose our lack of expertise”. The participants also pointed out that it would help when the principals are also able to lead computers in education. They added that unfortunately some of the school leaders are also not strong in digital technology and computer knowledge. The five principals in the study also agreed that change initiatives should start with the school management teams because when "they buy the initiatives, it would be easy to sell these to the rest of the staff". Another one emphasised the idea of instructional leadership to be sustained if computers in education are to be successful especially where there is much resistance. One school principal for example, highlighted the need to magnify the importance of computers at all times because teachers might not be aware of this crucial aspect in education today.

Morris (2010) contends that barriers to the use of ICT involve a lack of teacher awareness about "what technologies are available and how they can be used to support the delivery of the curriculum". Morris (2010: p. 151) adds:

If teachers are not able to implement and use the resources they already have available to them, then time and training would appear to be the main factors in preventing this happening. Time not just to locate and learn how to use these resources, but time to be shown, and practice, how they can be used in relevant ways to support subject teaching...

...with regard to new and emerging technologies, greater collaboration may be needed between pupils and teachers to facilitate the development of teaching and learning in this area.

Minty \& Pather (2014) also declare that for ICT to be well integrated in the classroom, teachers need to change their teaching style and of teachers in many schools is questionable. In one school although the computers were there, the principal had locked them in a storeroom because "I do not want them to be stolen". Only three of her staff of 29 teachers could use computers. Such a principal does not appear to see an urgent need for her teachers to be computer literate. She also sees computers as subject specific as she felt that teachers teaching language and biology for example, did not have to be computer literate.

Arguably, the major challenge that South African education has is the approach of ICT training that might not have always been useful in enabling teachers to be competent. Teachers need effective and meaningful ICT workshops that would boost their computer competence. Fourteen participants in the study maintained that they lacked the competence necessary in computer education or digital technology in the classroom. Yet, this com- 
petence has been a crucial aspect in many countries. Johannesen, Ogrim, \& Giaever (2014) argue that in the Norwegian system that ICT competence needs to be understood from a broader perspective. They point out that teachers need use a framework that would stress teaching of about and with ICT. Furthermore, Johannessen et al. argue that teachers need to be prepared to meet the expectations set out in the national curriculum and facilitate the development of digital competence among students.

Therefore, the above arguments can be summed up by stating that teacher competence in ICT will be enhanced by continuous professional development. If any effective framework is to be achieved teachers' needs have to be fulfilled. Regarding this aspect Al-Madani \& Allaafiajiy (2014) suggest that governments may have to provide enough and confident trainers to train teachers. "Teachers should be constantly encouraged to undertake professional development and continually pursue mental and physical skills required of them in the age of globalisation” (Al-Madani \& Allaafiajiy, 2014: p. 34).

Teacher competence in the study was influenced by various factors. The older the teachers were the more likely they maintained that they could not improve their competence. For others computer competence cannot be improved easily because they do not ask for guidance from peers but instead prefer to work alone as highlighted above. Yet Tambunan (2014) contends that teachers' competence in the field of ICT is influenced by the teachers' interpersonal communication, use of information technology and self-improvement of teachers. Furthermore, Tambunan (2014: p. 70) asserts:

To get optimal goal of learning requires teachers who are competent in managing learning. Teachers' competence in the field of information technology is a critical need to improve learning outcomes. The linkage between technology, dissemination of information on human resource development, and readiness of individuals' ability to work can begin from home (Chin \& Horton, 1994). Teachers are required to follow the development of technology to improve its information technology competence, in ensuring its position as a leader in the use of learning technology.

As evident in the study, there are numerous teachers who do not have this competence. It is difficult to positively bring change in the classroom when there is lack in competence. It is then crucial for Education departments to prepare school principals as instructional leaders who will lead change in ICT classrooms. When more ICT skills are invested in a school leader empowerment it is likely that other staff members can learn. Competence can change not only staff and pupil performance in computers but it will positively influence the attitudes towards ICT.

\subsection{Attitudes and ICT}

Teachers' attitudes are crucial in any innovation for teachers who do not have the right attitude will not be able to implement curricular changes appropriately. Even when teachers are competent in an innovation, they might not be successful in their classrooms when their attitudes are not positive. When planning to introduce changes, it is vital that the legislators should involve teachers who will be implementing these changes. When the new post-apartheid curriculum was introduced in South Africa in the late 1990s researchers cited teacher attitudes as one hindrance that made the implementation to be problematic. Fourteen of the twenty participants (and this included one principal) had a negative attitude towards computers in education. The majority of these participants maintained that computers in education will undermine teachers. They argued that it appears as if computers will replace their expertise "as pupils will now be concentrating on their tablets rather than teachers". Others though did not agree as they explained that it should start with teacher attitudes if the introduction of computers in education is to work. One participant summed this up when he stated:

The Department of Basic Education should try and change attitudes and perceptions. There are still many teachers who do not see the need for computers or any kind of digital technology in the classroom. For them the writing board and chalk are the best implements for any classroom. They feel that computers in classrooms will just confuse learners and divert their attention. It is the most difficult task for the Department, to change attitudes.

A number of teachers also developed attitudes against computers because they maintained that these were not amenable with the subjects they taught. These attitudes come about because computer assisted teaching brings certain challenges to teachers. Jalali et al. (2014) states that the integration of technologies into the classroom 
necessitates which the teachers embrace various classroom management procedures to maintain a more pupil-centred learning environment. This shift that teachers need has an impact on their attitudes. In this study those teachers whose attitude was negative experienced challenges in using the digital technologies. It also appears that when the computers were introduced in the sampled schools, there was less attention given to the changing of teacher attitudes. The attitudes of newly qualified staff were different from that of experienced teachers. Recently qualified teachers were more positive because they stated that they were used to computers at the institutions of higher learning where they came from. The latter is in tandem with Abbott \& Faris' (2000) arguments who pointed out that increases in positive attitudes toward computers may be a consequence of instructional approaches as well as meaningful assignments that need technology. The current teacher education programmes should plan to use technology widely for this will enhance teacher preparation for digital technology. Abbott \& Faris (2000) also declare that teacher education programmes should not only teach how to use hardware and software "but also teach them how to incorporate computers into their teaching strategies and activities. Thus, the courses we teach should reflect the principles of teaching and learning to which we adhere". All these will help change the teacher attitudes. When the Department of Basic Education runs workshops, they should be meaningful and among others be able to change teacher attitudes.

In this study it was clear that not all participants favoured the introduction of ICT in their curriculum. The attitudes were linked to competence; because many felt inadequate when it came to computer use the attitudes were negative. Singh \& Chan (2014) argue the teachers' knowledge of how to utilise technologies has a crucial effect on using these effectively. Furthermore, they point out that teacher attitudes have a huge role to play on the use of technologies. When teachers are not positive towards ICT, the implementation of ICT will falter. In this study it is clear that teachers are threatened by ICT and this leads to negative attitudes. However, studies have shown that attitudes change to positive when teachers are encouraged and given training and facilities for them to use ICT (Copriady, 2014).

Copriady (2014: p. 121) asserts:

...teachers' motivation is a mediator on their willingness to apply ICT in their teaching and learning; this is very much associated with knowledge, so teachers must be able to apply the knowledge to use ICT with their own information technology skills. Frequent use of the applications will in fact improve the skills and capability, which in the long run increase the application of ICT in teaching and learning. Sustainable efforts are required to improve the skills of using ICT.

Teacher attitudes will be positive when the attempts are made to improve their ICT skills. According to Copriady teachers become motivated to use ICT when they are ready to apply ICT in their learning and teaching.

\subsection{Limitations of the Study}

My study was worthwhile with scholarly value but had numerous limitations. The sample used was small and the study was conducted in one province out of 9 South African provinces. A quantitative study across the provinces with more evenly distributed gender and teacher experience would have brought more credible and generalizable results. Furthermore, the study would have gained more had I used a comparative approach across various ethnic groups. Even with these limitations though, the study's findings may inform future and broad quantitative studies on the topic.

\section{Conclusion}

The introduction of computers envisaged in Gauteng Province schools needs to be commended. The $21^{\text {st }}$ century we are in needs people who have high digital competence. ICT is here and it heralds the coming decades that will transform the way which things are run in schools. However, this study demonstrates that schools will need teachers who will accept the paradigm shifts because they understand teaching about ICT and using ICT to teach. The Department of Basic Education should support meaningful ongoing teacher workshops that would empower school managers and their teachers. It should also be critical to magnify the role of teachers because the digital tools do not teach for it is effective teachers who will implement any innovations. When teachers do not feel confident and have negative attitudes towards computers, digital classrooms will hardly work. In a globalised world, the digital classroom is unavoidable. Teachers who are prepared to be agents of change and change agents will embrace computers and technologies to advance learning in their classrooms. Effective school man- 
agement teams will play a role in preparing their teachers for change. All teachers will embrace computers when they are clearly shown what computers stand for; that is education for the future.

\section{References}

Abbott, J. A., \& Faris, S. E. (2000). Integrating Technology into Pre-Service Literacy Instructions: A Survey of Elementary Education Students’ Attitudes toward Computers. Journal of Research on Computing in Education, 33, 149-161. http://dx.doi.org/10.1080/08886504.2000.10782306

Al Harbi, H. E. (2014). Towards Successful Implementation of ICT in Education. Proceedings of the 2014 WEI International Academic Conference, Vienna, 13-15 April 2014, 36-46.

Al-Madani, F. M., \& Allaafiajiy, I. A. (2014). Teachers' Professional Development on ICT Use: A Saudi Sustainable Development Model. Proceeding of the 2nd International Conference on Social Sciences Research ICSSR 2014, Kota Kinabalu, Sabah, June 2014.

Al Mulhim, E. (2014). The Barriers to the Use of ICT in Teaching in Saudi Arabia: A Review of Literature. Universal Journal of Educational Research, 2, 487-493.

Alnahdi, G. (2014). Assistive Technology in Special Education and the Universal Design for Learning. The Turkish Online Journal of Educational Technology, 13, 18-23.

Blackberry, G., \& Woods, D. (2014). Teachers and Pupils Incorporated: Developing a Co-Constructed Classroom. In S. Younic., M. Leask, \& K. Burden. (Eds.), Teaching and Learning with ICT in the Primary School, (pp. 130-141). Oxon: Routledge.

Blu Dot (Online). How Are Tablets Changing Africa’s Primary Schools Education? http://bdot.co.uk/tablets-changing-africas-primary

Brink, H. I. (2000). Fundamentals of Research Methodology for Healthcare Professionals. Cape Town: Juta.

Carolan, S., Magnin, M., \& Kabalu, A. (2014). Sparking a Digital Revolution: Digital \& Educational Tools in Fragile and Emerging Learning contexts. Digital Intelligence 2014, Nantes, September 2014.

Castano-Munoz, J., Duart, J. M., \& Sancho-Vinuesa, T. (2014). The Internet in Face-to-Face Higher Education: Can Interactive Learning Improve Academic Achievement? British Journal of Educational Technology, 45, 149-159. http://dx.doi.org/10.1111/bjet.12007

Chigona, A., Chigona, W., \& Davids, Z. (2014). Educators’ Motivation on Integration of ICTs into Pedagogy: A Case of Disadvantaged Areas. South African Journal of Education, 34, 1-8. http://dx.doi.org/10.15700/201409161051

Copriady, J. (2014). Self-Motivation as a Mediator for Teachers' Readiness in Applying ICT in Teaching and Learning. TOJET: The Turkish Online Journal of Educational Technology, 13, 115-123.

Curtis, S. (2014). Digital Learning: How Technology Is Reshaping Teaching (Online). The Telegraph. http://www.telegraph.co.uk/technology/news/11051228/Digital-learning-how-technology-is-reshaping-teaching.html

Domalewska, D. (2014). Technology-Supported Classroom for Collaborative Learning: Blogging in the Foreign Language Classroom. International Journal of Education and Development Using Information and Communication Technology, 10, 21-30.

Ermeley, Z., Ay, K. M., Alhindawy, M., Omair, O., \& Al Ghafery, N. (2014). The Effect of Electronic Teaching on Improving the Level of Some Gymnastic Skills. Life Science Journal, 11, 790-793.

Giller, G. (2014). Developing Countries still Far from Closing Digital Divide. Scientific American. http://blogs.scientificamerican.com/observations/

Hamilton, L., \& Corbett-Whittier, C. (2013). Using Case Study in Education Research. Los Angeles, CA: Sage. http://dx.doi.org/10.4135/9781473913851

Higgins, S. (2014). Does ICT Improve Learning and Teaching in Schools? http://dysgu.llyw.cymru/docs/learningwales/publications/121122ictlearningen.pdf

Jalali, S., Panahzade, V., \& Firouzman, A. (2014). Attitude towards Computers and Classroom Management of Language School Teachers. International Journal of Instruction, 7, 1-16.

Johannesen, M., Ogrim, L., \& Giaever, T. H. (2014). Notion in Motion: Teachers’ Digital Competence. Nordic Journal of Digital Literacy, 9, 300-312.

Minty, R., \& Pather, E. V. (2014). The Integration of ICTs in the Teaching and Learning of Mathematical Literacy: A Study Conducted in Eight Schools in Gauteng, South Africa. International Journal of Science, Commerce and Humanities, 2, 47-60.

Morris, D. (2010). E-Confidence or Incompetence: Are Teachers Ready to Teach in the 21st Century? World Journal on 
Educational Technology, 2, 141-154.

Ndibalema, P. (2014). Teachers' Attitudes towards the Use of Information Communication Technology (ICT) as a Pedagogical Tool in Secondary Schools in Tanzania: The Case of Kondoa District. International Journal of Education and Research, 2, 1-16.

Sabanci, A., \& Ozyildirim, G. (2014). The Effect of ICT Usage on the Classroom Management: A Case Study in Language Teaching. International Review of Social Sciences and Humanities, 7, 232-245.

Singh, T. K. R., \& Chan, S. (2014). Teacher Readiness on ICT Integration in Teaching-Learning: A Malaysian Case Study. International Journal of Asian Social Science, 4, 874-885.

Struwig, F. W., \& Stead, G. B. (2004). Planning, Designing and Reporting Research. Cape Town: Pearson.

Tambunan, H. (2014). Factors Affecting Teachers' Competence in the Field of Information Technology. International Education Studies, 7, 70-75. http://dx.doi.org/10.5539/ies.v7n12p70 